\title{
Developing Autonomy through the School Extra Feeding Program: Experimental Research of 7 Years Old Children in Elementary School
}

\author{
Neneng Tasu'ah ${ }^{\mathrm{a}}$

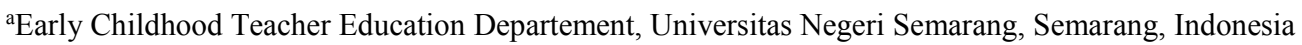

Corresponding e-mail: nenengtasuah@gmail.com

\begin{abstract}
The aims of this research was to understand comprehensively the influence of extra feeding activities toward independence children (Experiment in student class I at SDN Pejaten Barat, South Jakarta, 2013). The method used in this study is the experimental method with Children independence as the main problem which is the dependent variable. While first independent variable is the Extra Feeding activity (in this study is Cooking Fun activities and activities Role Playing) and the second independent variable is the parenting parent (in this study is the pattern of otoritarian parenting, democratic and permissive). In this study the sampling technique to be used the multistage cluster sampling. The sample in this study is in two elementary school SDN Pejaten Barat 12 and SDN Pejaten Barat10 each class have a number of students of approximately 30 students so that a total number of 60 students, but at the time of the study the researchers only select students based on parenting questionnaire results by category otoritarian parenting, permissive, democratic and 10 students respectively so that the sample in this study were 30 students as control class in SDN Pejaten Barat 10 and 30 students as an experimental class at SDN Pejaten Barat 12. This study is a design experiment with designs factorial $2 \times 3$. Therefore, data analys is using ANOVA two lines, if tested the difference, followed by Tukey's testor Scheffe test to determine which one is higher.The finding lead to the recommendation to use extra feeding activities and parenting to improving independence children. And teacher should be free to use learning methods especially extra feeding activities.
\end{abstract}

Keywords: extra feeding activities(fun cooking and role play), independence children

\section{INTRODUCTION}

To be independent, a person needs opportunities, support and encouragement of family and the environment around them to achieve autonomy for themselves. At this time the role of parents and the response of the environment is needed for children as a booster for any behavior that has been done. Independence can thrive when given the opportunity to develop through exercises performed continuously and done early. The exercises can be in a form of giving a task without help, and of course these tasks are tailored to the child's age and abilities.

Independence exercise which is given to the child should be adjusted to the child's age. Selfreliance should also be taught to children as early as possible in accordance with their capabilities. Examples of exercises that can be granted independence as picking up toys after each play, put his own socks and shoes, and also at meal times and the ability to show reasonable and responsible emotions.
In addition to developing basic capabilities such as reading, writing, and basic mathematics, primary school age children are also taught on how to develop healthy behavior. Healthy behavior is taught through activities like cleaning the classroom together, bringing nutritious foods to school and so on. The children only have to bring nutritious meals at certain times. Through this program, the children are introduced to a wide variety of nutritious foods that is good for their growth and health. At the time of bringing the food, children can eat together with friends at the same time to teach children to learn independently starting from meal preparation, at meals, and after meals. In the course of eating together, it is expected that children are able to be independent and at the same time socialize with their friends.

On the activities of eating together or Extra Feeding, children are taught how to make simple yet nutritious foods. Children were introduced to various kinds of foods and also how to present it. The foods made children should be varied so that they do not easily get bored with the food. 
Extra Feeding activities can be done through the activities of Fun Cooking. Fun Cooking is a cooking activity that can be done by children in a fun way. In this activity, children can cook their own food, both individually and in groups. Children were introduced to various kinds of produces and simple cooking utensils. Children are taught on how to use and maintain the cooking utensils. In addition, children were also introduced cooking equipments that might cause danger and how to avoid such situation.

Fun Cooking activities is an activity that train children to learn independently in preparing food for themselves and at the same time teaches children skills that can be useful throughout the ages. This activity can be given gradually from simple cooking to a rather difficult one in accordance with the child's developmental level. Children are taught to make food that does not need to be cooked first, then they will be introduced to use the ingredients that need to be cooked thoroughly. Fun cooking activities are appealing to children because the children feel happy and can create food creations as they please.

But in fact, most of the parents are still lacking in instilling the values of self-reliance. It is characterized by the frequent occurrence of conflicts between parents and children due to some parents' lack of temper in raising their children. Parents do not provide opportunities for their children to be able to do things themselves such as children want to eat alone but parents forbid them because it might create a mess.

The activity to eat together or Extra Feeding in Primary Schools still received less attention, because schools feel that these activities require more attention such as preparing the food menu, until the presentation for children. Teachers pay more attention to achieving the targets that must be mastered by children so that activities like this did not really receive proper attention. Teachers were also too focused on academic subjects that the results will be reported to parents.

Based on the above problems, the researchers are interested in examining whether Extra Feeding activity and parenting style influence the children's independence.

The formulation of the problem in this study are: "Is there any different independency between the children who were given Fun Cooking activity and the children who were given Role Play activity for the first grade students at Pejaten Elementary School, South Jakarta, in 2013?"

\section{THEORETICAL STUDIES}

\subsection{The Definition of Independence}

The role of family and the environment can strengthen any behavior. Independence appears and functions when students find themselves in a position that requires a certain level of confidence. According to Steinberg (in Desmita, 2010) independence is different from not relying on someone because not relying on someone is part of gaining independence [1]. According to Chaplin (2002) independence is the autonomy of every individual, to be an entity that can govern, control and determine himself [1]. While Seifert and Hoffnung (1994) defines autonomy or independence as "the ability to govern and regulate one's own thoughts, feelings, and actions freely and responsibly while overcoming feelings of shame and doubt [1]. " Thus it can be understood that the independence or autonomy is the ability to control and regulate the thoughts, feelings and actions for themselves freely and on their own to overcome feelings of shame and doubt.

Erikson (in Desmita, 2011) declared independence is an attempt to be away from the parents with the intention to find themselves through the process of achieving self identity that is progressing toward a steady individuality and the ability to stand alone[1]. Independence can be seen from the ability to be away from the bonds with parents and moving away from parents because someone has been able to be on his own. Furthermore, because the children are free, then they will develop the effort to initiate and try (there are efforts to solve the problem). Children will decide whether they will use their motor skills.

The following are the forms of independence by Robert Havighusrt (1972) :

1. Emotional independence, the ability to control their own emotions and not dependent on other people's emotional needs

2. Economic independence, the ability to regulate their own economies and not dependent on the economic needs of others

3. Intellectual independence, namely the ability to cope with various problems on hand.

4. Self-reliance is the ability to hold social interaction with others and do not depend on the actions of others [1]. 


\subsection{The Definition of Extra Feeding}

Maximizing the growth and development of children is a process that lasts a lifetime. One form of learning that can improve children's growth is through Extra Feeding activities. Such activities may not be a prerequisite in the development of the vast improvement. However, Extra Feeding activities can help children's growth because in these activities both hard skills and soft skills are trained. During Extra Feeding activities not only children's ability related to the development of independence alone which is being developed, but also moral and religious values, social, emotional, cognitive, physical motor skills, self-reliance and art.

Extra Feeding activities are the activities of eating together. The implementation of eating together has its own special aspect because in addition to learning on how to eat good and right, children are also taught to recognize food, love it, and using dining utensils properly. At the age of 4-6 years old children are active consumers who are able to choose and refuse food, so the planting of healthy behaviors should have started early.

The healthy behavior of a person is made up of the school environment, the home and the surrounding environment. One of the way to start healthy behavior within the school is by organizing Extra Feeding activities. The objective of Extra Feeding or eating together at the school is for children to know the difference and to be able to choose healthy and nutritious food, the children understand the need of their body, are able to perform the procedure of eating right and being able to behave in accordance with the environment.

The meaning of additional foods is the foods or drinks that contain nutrients given in early childhood in order to meet specific nutritional needs. While supplementary feeding is the activity of giving food or drink to increase nutrients intake. The form of additional food is served with an interesting shape, easy to eat, and also considerable portion sizes (are not too filling).

Extra Feeding activitiesis a series of patterned meal together to improve children's growth, both physical and psychological. Eating habits at school can drive good eating habits in children, which is expected to be one that is embedded behaviors and become a good habit. According to Ningsih (in Novarizki , 2010), " Extra Feeding activity at school leads to the children's habit on how to eat better. The point is that as a means of influencing the behavior of children so that they can apply the knowledge of nutrition in their daily eating habits
[2]. Extra Feeding activities are beneficial to be able to raise the nutritional status of children and determine the quality of Human Resources (HR) in the future, and therefore the nutritional status of children should always be on the increase because it will affect the intelligence of a nation. Poor nutritional status at pre-school age children can reduce the level of intelligence of the children.

Extra Feeding activities which were being held at the school can be used as a media to educate children in order to receive, like, and choose foods that are good, also to determine the amount of sufficient food quality. This assumption is supported by Febriyanti (in Yuniastuti, 2008), who states that eating habits is a learning process that occurs a lifetime, from birth to adulthood and will continue forever [3]. A person's eating habits are habits of the family, because the individual living in the family. Good eating habit is one indicator that food consumption is diverse in every food. Through the organization of food in school, children learn a lot of things, ranging from self-reliance, discipline, courtesy, sharing with friends, get to know important nutrients contained in foods, even for children who are often difficult to eat will eat during this activity, because the atmosphere and friends at school affected the environment. Fun Cooking is an activity that develops skills in food processing by using materials and tools that are real.

Various activities in fun cooking can support all aspects of development in children, such as: aspects of language, cognitive, motor, socio-emotional and self-reliance (Coughlin, 1997) [4]. This fun cooking activity should not only be done in the kitchen, but also can be done in the classroom or school yard. The most important thing is, the place to do fun cooking should be prepared to be safe for children during the move. So that the activities will run smoothly, the children can work in small groups. Through small groups, it is expected they will also develop tolerance, mutual respect, mutual help and sharing.

\subsection{The Definition of Role Play}

Playing is the main activity which started to appear since infants aged 3 or 4 months. Play is important for cognitive, social and personality developmentof children in general. According to Freud, playing is like fantasia or daydream. Through a fantasy, a person can project hope and also personal conflict. Also according to Bruner playing is a means to develop creativity and flexibility. While playing, 
what is more important for children is the meaning of the play and not the end result. Through the process of playing children are given an invaluable opportunity to practice social skills and independence.

Furthermore, Bateson argued that playing activities are good to stimulate interest in the communication aspects. Such as when playing a role, a child can change roles between the pretend role and true identity. While playing, almost all aspects of the child development are stimulated and well developed. This statement is in line with Catron and Allen ( in Sujiono, 2010), who argued that playing can provide immediate effect on all areas of development[5]. Children can take the opportunity to learn about themselves, others, and the environment.

Moeslichatoen (2004), classifies play activities based on the predilection of children, they are, free and spontaneous play, pretend play, play by building or composing, and playing and exercising [6]. Play a role in helping children to find meaning in social life environment is beneficial to them so that there is the possibility of a personal dilemma that can be solved with a friend. In addition, children also learn that in life it requires the help of others. In other words, role play is useful in helping children through the process of social groups.

According to Gowen (in Arriyani \& Wismiarti, 2010) role play is viewed as a strength on which to base the development of creativity, stages of memory, teamwork, vocabulary, the concept of family relationships, self-control, taking the viewpoint of spatial skills, affection skills viewpoint and the skills of making point of view [7].

According to Berger (in Tedjasaputra, 2007) playing activities can be distinguished as follows:

\section{METHOD}

The method used in this study is the experimental method with the independence of the Child as the main problem is the dependent variable. While the first independent variable is Extra Feeding Activity (in this study is the activity of Fun Cooking and the Role Playing activity).

In this study, the sampling technique used was multistage cluster sampling. The sample in this study were in two elementary schools, namely Pejaten Barat10 Elementary school and Pejaten Barat 12 Elementary School. Each had approximately 30 first grade students so that a total number of students in this research were 60 students. The sample in this study were 30 students as the control class in Pejaten Barat 10 Elementary school and 30 students as an experimental class at Pejaten Barat 12 Elementary School.

The data were analyzed by descriptive and inferential. The analysis of descriptive data are the results of data processing with the aim that the data set was significant (meaningful). The description of the data consists of: the presentation of data and the display of size/ central tendency and the size of deployment tendency.

The descriptive analysis consist of data presentation with a list of frequency distribution and histogram. The central size comprises: calculating the mean, median, mode. The size of the deployment is composed of: span (range), the deviation (deviation), variance, and standard deviation (standard deviation) of each variable.

In order for a hypothesis test to be done, first the hypothesis requirements should be tested, including normality test and homogeneity test. Normality test was intended to determine whether the independence score as the results of this study were normally distributed or not. To test for normality, I used Liliefors test, while homogeneity test data is done by Barlett test.

This study was an experimental study with a draft design Treatment by level $2 \times 3$. Therefore, the analysis of data using ANOVA two-way, if there is proven to be differences, it was followed by Tukey's test or Scheffe test to determine which one is higher.

\section{RESULTS AND DISCUSSION}

After testing the requirements analysis and the calculation analysis results showed that the samples were normally distributed and had homogeneous variant then the next was hypothesis testing using miscellany analysis (ANOVA) two-way. If the calculations show further interaction it will be further tested with T Test. Summary of the results of calculations using ANOVA two-way can be seen in the table below: 
Table 1. ANOVA two-way calculation results

\begin{tabular}{|c|c|c|c|c|c|c|}
\hline Source & \multirow{2}{*}{ df } & \multirow[b]{2}{*}{ JK } & \multirow[b]{2}{*}{ RJK } & \multirow[b]{2}{*}{$F_{\text {value }}$} & \multicolumn{2}{|c|}{$\mathbf{F}_{\text {table }}$} \\
\hline $\begin{array}{c}\text { Varian } \\
t\end{array}$ & & & & & $\begin{array}{c}0,0 \\
5\end{array}$ & $\begin{array}{c}0,0 \\
1\end{array}$ \\
\hline A & 1 & $\begin{array}{c}11276.4 \\
0 \\
\end{array}$ & 11276.40 & $6.90 *)$ & $\begin{array}{c}4.0 \\
2 \\
\end{array}$ & $\begin{array}{c}7.1 \\
3 \\
\end{array}$ \\
\hline B & 2 & $\begin{array}{c}79353.3 \\
0 \\
\end{array}$ & 158706.60 & $97.16^{*)}$ & $\begin{array}{c}3.1 \\
7 \\
\end{array}$ & $\begin{array}{c}5.0 \\
2 \\
\end{array}$ \\
\hline $\mathrm{AxB}$ & 2 & $\begin{array}{c}12436.9 \\
5 \\
\end{array}$ & 24873.90 & $\begin{array}{c}15.23 * \\
*)\end{array}$ & $\begin{array}{c}3.1 \\
7 \\
\end{array}$ & $\begin{array}{c}5.0 \\
2 \\
\end{array}$ \\
\hline $\mathrm{D}$ & $\begin{array}{l}5 \\
4 \\
\end{array}$ & $\begin{array}{c}30.2478 \\
5 \\
\end{array}$ & $\begin{array}{c}1633.3836 \\
8 \\
\end{array}$ & - & & \\
\hline Total & $\begin{array}{l}5 \\
9 \\
\end{array}$ & $\begin{array}{c}103096 . \\
9 \\
\end{array}$ & - & - & & \\
\hline $\begin{array}{l}\text { Notes: } \\
\text { df } \\
*) \\
* *) \\
\text { ns }\end{array}$ & $\begin{array}{l}=\mathrm{D} \\
=\mathrm{F} \\
=\mathrm{F} \\
=\mathrm{n}\end{array}$ & $\begin{array}{l}\text { egrees of } \\
\text { test signif } \\
\text { test very } \\
\text { t signific }\end{array}$ & $\begin{array}{l}\text { reedom } \\
\text { gance on lev } \\
\text { gnificant on } \\
\text { it on level } 0\end{array}$ & $\begin{array}{l}0,05 \\
\text { level } 0,01 \\
05\end{array}$ & & \\
\hline
\end{tabular}

The difference between the children who were treated with Fun Cooking activity and the children who were treated with Role Play activity:The hypothes is of the study there is a significant difference in the child's independence among children treated with Extra Feeding activity with Fun Cooking with children treated by using Extra Feeding activity with Role Playing. The independence of children treated with Extra Feeding activity with Fun Cooking is higher than the child's independence treated with Extra Feeding activity with Role Playing.

The calculation result data via ANOVA two-way in the table above, is explained that the value of Fvalue $=6.90$ is greater than the value Ftable $=4.02$ at 0.05 significance level. This shows that $\mathrm{Ho}$ is rejected while the $\mathrm{H} 1$ is accepted. It can be concluded that there are significant differences between the Extra Feeding Activity with Fun Cooking and Extra Feeding Activity with Role Playing.

As already described in advance that the average score obtained by using Extra Feeding Activity with Fun Cooking (A1) is 37.4667 and groups Extra Feeding Activity with Role Playing (A2) is 32.6333 . Thus it can be stated that the independence of first grade students of Pejaten Barat 12 Elementary School treated with Extra Feeding Activity with Fun Cooking is higher than the child's independence given Extra Feeding activity with Role Playing.

Based on the analysis of data as has been described previously and continued to test the hypothesis, there are a number of research findings that need to be discussed further. So that the findings can be used as a reference in order to improve the quality of education, especially the independence of the child in the first grade students of Pejaten Barat Elementary School, South Jakarta, the findings of the research include the following: The independence of children between the Extra Feeding Activity with Fun Cooking and Extra Feeding Activity with Role Playing. There are significant differences in the aspect of students' independence, the children's independence treated with Extra Feeding Activity with Fun Cooking is higher than the children's independence given Extra Feeding activity with Role Playing.

The difference is due to the Extra Feeding Activity with Fun Cooking by combining the function of education with entertainment content in the form of a game. The game aims to create an attractive learning environment, thus making the learning process of children in school more meaningful, enjoyable and avoid boredom. Sugeng Santoso states that defines the emotional implications on the development of the Extra Feeding Activity can provide children the experience of emotional control when having meals along with their classmates. Children can learn when to queue patiently for example for washing hands and so on. By using Extra Feeding Activity with Fun Cooking, it will be a more fun learning activity for children. Besides games contribute more meaning to children in learning and is a significant activity for children.

According to Sunita Almatsier, food has three functionsfor individual: (1) a function of biology, food is to provide nutrients for the human body in order to work or sustain life. (2) the function of psychology, food is to meet the needs associated with satisfaction, emotions, and behavior. (3) social function, food is to meet the needs of social interaction in the group or community. Therefore events such as Extra Feeding Activity with Fun Cooking can also optimize the independence of the children because children were directly interact during the treatment. So that the interaction is multi direction between fellow children and children with the teacher.

While treatment using Extra Feeding activity with Role Playing is also a fun learning for children, help children to obtain information in accordance with the age and life that can be applied in everyday life, but not optimally develop the child's independence. 


\section{REFERENCES}

[1] Desmita. (2011). Psikologi Perkembangan. Bandung : Remaja Rosdakarya.

[2] Novarizki, Galuh. (2010). Modul Kesehatan dan Gizi Anak Usia Dini: Semarang.

[3] Yuniastuti, Ari. (2008). Gizi dan Kesehatan. Yogyakarta : Graha Ilmu.

[4] Coughlin, Pamela. A. (1997). Creating ChildCentered Classroom: 3-5 Years Old. Washington: Children's Resources International Inc.

[5] Sujiono, Yuliani. (2010). Bermain Kreatif Berbasis Kecerdasan Jamak. Jakarta: Indeks

[6] Moeslichatoen. (2004). Metode Pengajaran di Taman Kanak-kanak. Jakarta: Indeks

[7] Arriyani, Neni \& Wismiarti. (20100. Panduan Pendidikan Sentra untuk PAUD (Sentra Peran). Jakarta: Pustaka Al-Falah.

[8] Tedjasaputra, Mayke. S. (2007). Bermain, Mainan, dan Permainan. Jakarta: Grasindo. 